\title{
Possibilities of High Resolution Inductively Coupled Plasma Optical Emission Spectrometry in the Determination of Trace Elements in Environmental Materials
}

\author{
Nikolaya Velitchkova, ${ }^{1}$ Olga Veleva, ${ }^{1}$ Serafim Velichkov, ${ }^{2}$ and Nonka Daskalova ${ }^{2}$ \\ ${ }^{1}$ Geological Institute, Bulgarian Academy of Sciences, Acad. G. Bonchev Street, Building 24, 1113 Sofia, Bulgaria \\ ${ }^{2}$ Institute of General and Inorganic Chemistry, Bulgarian Academy of Sciences, Acad. G. Bonchev Street, Building 11, 1113 Sofia, Bulgaria
}

Correspondence should be addressed to Nonka Daskalova; das15482@svr.igic.bas.bg

Received 31 May 2013; Accepted 24 July 2013

Academic Editor: Kong-Thon Tsen

Copyright (C) 2013 Nikolaya Velitchkova et al. This is an open access article distributed under the Creative Commons Attribution License, which permits unrestricted use, distribution, and reproduction in any medium, provided the original work is properly cited.

\begin{abstract}
This paper presents new quantitative data for the spectral interferences obtained by high resolution $40.68 \mathrm{MHz}$ radial viewing inductively coupled plasma optical emission spectrometry (HR-ICP-OES) in the determination of $\mathrm{Zn}, \mathrm{Cd}, \mathrm{Sb}, \mathrm{Cu}, \mathrm{Mn}, \mathrm{Pb}, \mathrm{Sn}$, $\mathrm{Cr}, \mathrm{U}$, and $\mathrm{Ba}$ in environmental materials in the presence of a complex matrix, containing $\mathrm{Al}, \mathrm{Ca}, \mathrm{Fe}, \mathrm{Mg}$, and Ti. The $\mathrm{Q}$-concept for quantification of spectral interferences was used. The optimum line selection for trace analysis of a variety of multicomponent matrices requires the choice of prominent lines, which are free or negligibly influenced by line interference problems. The versatility of $Q$-concept as basic methodology was experimentally demonstrated in the determination of trace of elements in soil and drinking water. The detection limits are lower in comparison with corresponding threshold concentration levels for soil and drinking water in accordance with environmental regulations. This paper shows the possibilities of present day ICP-OES equipment in the direct determination of trace elements (without preconcentration of impurities) in environmental samples.
\end{abstract}

\section{Introduction}

Industrial activities, urban waste treatment, and vehicle exhaust are some of the sources causing large quantities of toxic elements as contamination in atmosphere, water, and soil. In the case of chemical toxicity, elemental analysis of environmental materials such as soil, sediments, natural and waste water, and air particulates can play an important role in the rapid detection and identification of the key element. The health risk of an element is determined by the stability and environmental mobility of the particular species of the element. Toxic effects of large number of elements are well known [1-10].

Due to the adverse health effects of different elements, detection of trace amount of these elements in any environmental sample related to human being is very important. Determination of these elements requires sufficiently sensitive techniques for detection. In the literature, there are many techniques including flame atomic absorption spectrometry (FAAS) $[8,11]$, electrothermal atomic absorption spectrometry (ETAAS) [12, 13] inductively coupled plasma optical emission (ICP-OES) [14-21], mass spectrometry (ICPMS) [22-24], X-ray and total reflection X-ray fluorescence techniques (TXRF), atomic fluorescence spectrometry (AFS), microwave-induced plasma source (MIP-OES and MIPMS), laser-induced breakdown spectroscopy (LIBS), laserexcited atomic fluorescence spectrometry (LEAFS), and glow discharge mass spectrometry (GD-MS) $[25,26]$.

Modern environmental science maintains an interest in methods, which ensure the following important characteristics: (a) multielement analysis of a wide variety of environmental sample types; (b) it must be able to detect large number of elements at threshold concentration levels for a different type of samples. Among the modern instrumental methods for determination of trace elements, inductively coupled plasma optical emission spectrometry (ICP-OES) is very powerful [14-21].

At present, accurate ICP-OES analysis of environmental materials, other than natural or waste water, requires dissolution of the samples. The method is influenced by the 
blank contribution from all steps during sampling and sample preparation. The blank contribution might be considerable and must be controlled when working at trace concentration $[33,34]$.

Considerable systematic errors in ICP-OES may arise from different matrix effects (nonspectral and spectral interferences) [35-37]. Nonspectral matrix effects change the sensitivity of the net analyte signals, that is, influence on the slope of the calibration curve [35]. An optimization of the analytical results in inductively coupled plasma with respect to the elimination of nonspectral matrix effects can be achieved by modifying the different operating parameters. Summarizing the investigation on nonspectral matrix effects in the presence of different matrices, the following conclusions can be drawn $[16,17,38-43]$ :

(i) the elimination of nonspectral matrix effects cannot be achieved by the optimization of the operating conditions in most of the cases. The robust plasma conditions are more appropriate when compared to the nonrobust plasma conditions [38-43];

(ii) by precise matching of the acid and matrix contents in both references and sample solutions, the nonspectral matrix effects can be totally removed, and an accuracy of analytical results can be ensured $[16,18,44]$.

Spectral interferences may drastically deteriorate the analytical characteristics of the ICP-OES. The most difficult samples, from this point of view, are the soil and different sediments. These materials normally contain high concentrations of $\mathrm{Al}, \mathrm{Ca}$, and $\mathrm{Mg}$, which cause significant background enhancement in many regions of the spectrum, high concentrations of $\mathrm{Fe}$, and to a lesser extent $\mathrm{Ti}$, which can give rise to serious line overlap interferences in the determination of trace elements [14].

The high resolution spectrometers can reduce the number of spectral interferences. However, once the band pass becomes equal to or smaller than the physical line width of the ICP emission lines, no further reduction in interferences will be gained by using higher resolution $[45,46]$. Therefore, the use of the high resolution spectrometers does not preclude the occurrence of spectral interferences. In this relation, two different steps can then be taken.

(i) A line may be chosen which is relatively free of spectral interferences. However, this will involve a tradeoff between spectral interferences and sensitivity, if the most intense line suffers from interference.

(ii) It may be possible to correct or compensate for the spectral interferences if the interferences can be identified and quantified. The letter approach is possible because of the stability of the ICP emission. However, the identification and quantification of all significant interferences may be a difficult task [46].

Boumans and Vrakking proposed the Q-concept for quantification of spectral interferences and "true detection limit" criterion for quantitative line selection and applied this concept to the determination of trace of rare earth elements in pure rare earth matrices $[47,48]$. Background emission intensity depends on the sample composition. Compared to a continuous background, an interfering line signal in the presence of a given matrix has to be considered as a contribution to the background that can be measured only with a much larger uncertainty. It was this insight that prompted the introduction of the concept of "true detection limits" $\left(C_{L, \text { true }}\right)$ to be distinguished from the "conventional detection limit" $\left(C_{L, \text { conv }}\right)$ and "common detection limit" $\left(C_{L}\right)$ for pure solvent [49-51].

The optimum line selection in the presence of onecomponent matrices for trace analysis implies the choice of prominent lines with minimum value of the true detection limit [48]. The optimum line selection for the trace analysis of a variety of multicomponent environmental samples requires a choice of the prominent lines, which are free or negligibly influenced by line interference problems $[16,18]$.

The optimization procedure of experimental conditions in the determination of trace of elements in complex environmental matrix by using $40.68 \mathrm{MHz}$ ICP and ICP-OES spectrometer HORIBA Jobin Yvon ULTIMA is presented in our previous paper. The general conclusions from investigations are that the lowest values for (1) detection limits in pure solvent; (2) line and wing background interferences; and (3) detection limits in the determination of trace of elements in different environmental samples are obtained under the optimal excitation conditions $\left(T_{\mathrm{exc}} \approx 7200 \mathrm{~K}\right)[16,18]$. The excitation temperature was measured by the Boltzmann plot method with ionic titanium lines [52].

The general purpose of the present paper is to show quantitative data for line and wing background spectral interferences in the determination of $\mathrm{Zn}, \mathrm{Cd}, \mathrm{Sb}, \mathrm{Cu}, \mathrm{Mn}, \mathrm{Pb}$, $\mathrm{Sn}, \mathrm{Cr}, \mathrm{U}$, and, $\mathrm{Ba}$ in the presence of complex environmental matrix (containing $\mathrm{Al}, \mathrm{Ca}, \mathrm{Mg}, \mathrm{Fe}$, and $\mathrm{Ti}$ as interferents) by 40.68 MHz ICP and high resolution spectrometer at optimal excitation conditions $\left(T_{\mathrm{exc}} \approx 7200 \mathrm{~K}\right)$. The data are needed for analytical atomic spectrometry in the analysis of all types of environmental samples: soil, sediments, water (surface, ground, and drinking), and atmospheric particulate matter.

\section{Materials and Methods}

2.1. Instrumentation. The experiments were performed with radial viewing ICP-OES system HORIBA Jobin Yvon ULTIMA 2 (Jobin Yvon, Longjumeau, France) equipment. The characteristics of the equipment and operating conditions are specified in Table 1 . The quantitative information about the type of spectral interferences was derived from the wavelength scans around the candidate (prominent) analysis lines in the presence of $\mathrm{Al}, \mathrm{Ca}, \mathrm{Mg}, \mathrm{Fe}$, and $\mathrm{Ti}$ as interferents.

The practical spectral bandwidth of the spectrometer was determined by measuring the full width at half maximum (FWHM) of Sm II line at $359.260 \mathrm{~nm}$ in the 1st order from 320 to $800 \mathrm{~nm}$ and of $\mathrm{Pb}$ II line at $220.353 \mathrm{~nm}$ in the 2nd order from $160 \mathrm{~nm}$ to $320 \mathrm{~nm}$. These lines have a physical width of $1.9 \mathrm{pm}$ and $1.4 \mathrm{pm}$, respectively, [53] and are therefore well suited for the measurement of the practical spectral bandwidth because the contribution of the physical width to 
TABLE 1: Specification of ICP-OES spectrometer: HORIBA Jobin-Yvon ULTIMA 2 (France) and ICP operating conditions.

\begin{tabular}{|c|c|}
\hline Monochromator & HORIBA Jobin-Yvon ULTIMA 2 \\
\hline Mounting & Czerny-Turner, focal length $1 \mathrm{~m}$ \\
\hline Grating & Holographic, 2400 grooves $\mathrm{mm}^{-1}$ \\
\hline Wavelength range & first and second order \\
\hline Entrance slit & $0.015 / 0.02 \mathrm{~mm}$ \\
\hline Exit slit & $0.02 / 0.08 \mathrm{~mm}$ \\
\hline Practical spectral bandwidth & $\begin{array}{l}5 \mathrm{pm} \text { in the } 2 \mathrm{nd} \text { order from } 160 \mathrm{~nm} \text { to } 320 \mathrm{~nm} \text {; and } 10 \mathrm{pm} \text { in } \\
\text { the } 1 \text { st order from } 320 \text { to } 800 \mathrm{~nm}\end{array}$ \\
\hline Detectors & High dynamic detectors based on PMT’s \\
\hline Radio frequency generator & Solid state RF $40.68 \mathrm{MHz}$ \\
\hline Frequency power output & $\begin{array}{l}40.68 \mathrm{MHz} \\
0.5-1.55 \mathrm{~kW}\end{array}$ \\
\hline Nebulizer & Meinhard, concentric glass, type TR $50 \mathrm{C} 1$ \\
\hline Spray chamber & JY Glass cyclonic spray chamber \\
\hline Plasma torch & Fully demountable torch \\
\hline Pump & Peristaltic, two channels, twelve-roller \\
\hline \multicolumn{2}{|c|}{ Operating conditions } \\
\hline Incident power, $(\mathrm{kW})$ & 1.00 \\
\hline Outer argon flow rate, $\left(\mathrm{L} \mathrm{min}^{-1}\right)$ & 13 \\
\hline Nebulizer, pressure, (bar) & 3.2 \\
\hline Carrier gas flow rate, $\left(\mathrm{L} \mathrm{min}^{-1}\right)$ & 0.4 \\
\hline Sheath gas flow rate, $\left(\mathrm{L} \mathrm{min}^{-1}\right)$ & 0.2 \\
\hline Sum $=$ carrier gas + sheath gas flow rate, $\left(\mathrm{L} \mathrm{min}^{-1}\right)$ & 0.6 \\
\hline Liquid uptake rate, $\left(\mathrm{mL} \mathrm{min}^{-1}\right)$ & 1.0 \\
\hline Observation height, $(\mathrm{mm})$ & 10 \\
\hline Excitation temperature $\approx T_{\mathrm{exc}},(\mathrm{K})$ & 7200 \\
\hline
\end{tabular}

the effective width is negligible for the present instrument [54]. In some cases, the practical spectral bandwidth is essentially larger than the resultant spectral slit (theoretical bandwidth, calculated from dispersion and slit width). This is due to aberrations $[45,48]$.

Here, we will note that the measurements were performed in the 2nd order of the spectrum (practical spectral bandwidth $5 \mathrm{pm}$ ) for the prominent lines of $\mathrm{Zn}, \mathrm{Cd}, \mathrm{Sb}, \mathrm{Mn}, \mathrm{Pb}$, $\mathrm{Sn}$, and Cr with wavelengths in spectral region $160-320 \mathrm{~nm}$. The wavelengths of the prominent lines of $\mathrm{Cu}, \mathrm{U}$, and $\mathrm{Ba}$ lie in the spectral region $320-800 \mathrm{mn}$, and the measurements were made in the 1st order (practical spectral bandwidth $10 \mathrm{pm}$ ).

The quantitative data for the spectral interferences were obtained in the presence of $2 \mathrm{mg} \mathrm{mL}^{-1} \mathrm{Al}, \mathrm{Ca}, \mathrm{Mg}, \mathrm{Fe}$, and $\mathrm{Ti}$ as interferents, separately. $Q$ values for line interference $\left[Q_{I}\left(\lambda_{a}\right)\right]$ and $Q$ values for wing background interference $\left[Q_{w}\left(\Delta \lambda_{a}\right)\right]$ were obtained around selected prominent lines of $\mathrm{Zn}, \mathrm{Cd}, \mathrm{Sb}, \mathrm{Cu}, \mathrm{Mn}, \mathrm{Pb}, \mathrm{Sn}, \mathrm{Cr}, \mathrm{U}$, and $\mathrm{Ba}$.

An example for the spectral scans over the spectral region around the prominent line of $\mathrm{Zn}$, central wavelength: $213.856 \mathrm{~nm}$ (Zn II line), and interferents: Fe $213.858 \mathrm{~nm}$ and Ti $213.835 \mathrm{~nm}$ is shown in Figure 1.

The scans were used for establishing the type of the spectral interferences as follows.
The total background signal in the presence of a complex environmental matrix is

$$
X_{B L}=X_{B}+X_{W J}\left(\Delta \lambda_{a}\right)+X_{I J}\left(\lambda_{a}\right),
$$

where $X_{B}$ is the solvent blank (due to the source and solvent); $X_{W J}\left(\Delta \lambda_{a}\right)$ is the wing background level with respect to the solvent blank for the interferents $(J=\mathrm{Al}, \mathrm{Ca}, \mathrm{Mg}, \mathrm{Fe}$, and $\mathrm{Ti}$ ); and $X_{I J}\left(\lambda_{a}\right)$ is the net interfering signals with respect to the wing background level $\left[X_{W J}\left(\Delta \lambda_{a}\right)\right]$ of the interferents $(J=\mathrm{Al}$, $\mathrm{Ca}, \mathrm{Mg}$, Fe, and $\mathrm{Ti}$ ).

The following signals were measured: $X_{A}, X_{B}$, $\left[X_{W J}\left(\Delta \lambda_{a}\right)\right]$, and $\left[X_{I J}\left(\lambda_{a}\right)\right]$. The measured signals were then reduced to sensitivities:

(i) the sensitivity of the analysis line $S_{A}$, defined as the net line signal $X_{A}$ per unit analyte concentration $C_{A}$;

(ii) the interferent sensitivities $\left[S_{W J}\left(\Delta \lambda_{a}\right)\right]$ and $\left[S_{I J}\left(\lambda_{a}\right)\right]$, defined as interferent signals $\left[X_{W J}\left(\Delta \lambda_{a}\right)\right]$ and $\left[X_{I J}\left(\lambda_{a}\right)\right]$, respectively, per unit interferent concentration $\left[C_{I J}\right]$.

Finally, the sensitivities were used for the calculation of the $Q$-values for wing background interference $\left[Q_{W J}\left(\Delta \lambda_{a}\right)\right]=\left[S_{W J}\left(\Delta \lambda_{a}\right)\right] /\left[S_{A}\right]$, the $Q$-values for line 


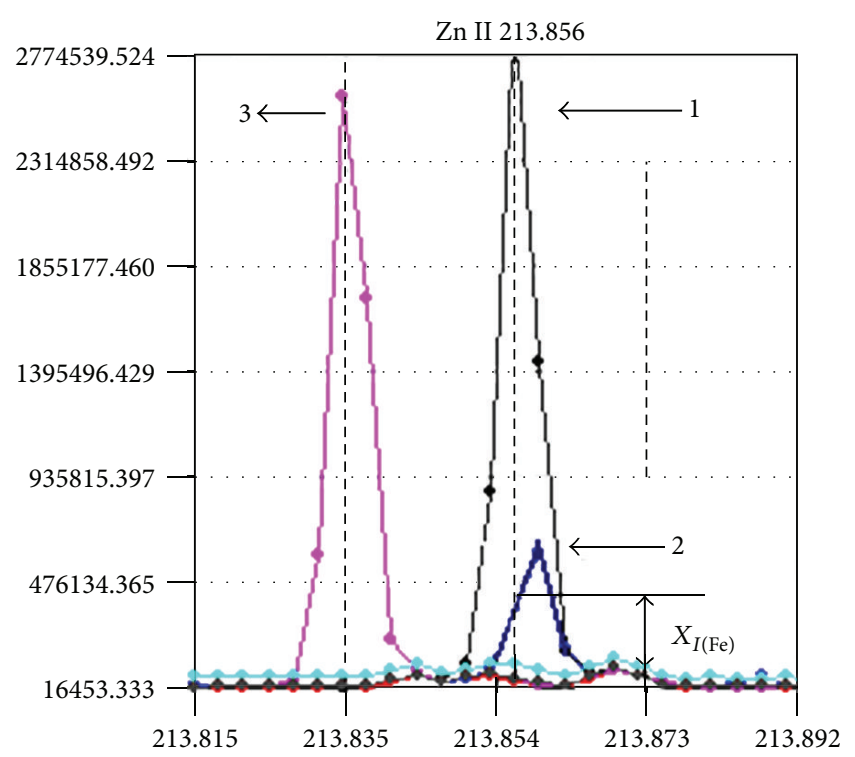

Figure 1: Spectral scans over the spectral region around the prominent line of $\mathrm{Zn}$ : central wavelength: $213.856 \mathrm{~nm}$ (Zn II line); interferents: Fe and Ti. (1) Central wavelength Zn II $213.856 \mathrm{~nm}$, $1 \mu \mathrm{g} \mathrm{mL}^{-1} \mathrm{Zn}$ in pure solvent; (2) interfering line: Fe $213.858 \mathrm{~nm}$, concentration of Fe $2 \mathrm{mg} \mathrm{mL}^{-1}$; (3) interfering line: Ti $213.835 \mathrm{~nm}$, concentration of Ti $2 \mathrm{mg} \mathrm{mL}^{-1}$; $\left[X_{I \mathrm{Fe}}\left(\lambda_{a}\right)\right]$ is the net interfering signals with respect to the wing background level $\left[X_{W \mathrm{Fe}}\left(\Delta \lambda_{a}\right)\right]$.

interference $\left[Q_{I J}\left(\lambda_{a}\right)=S_{I J}\left(\Delta \lambda_{a}\right) / S_{A}\right]$, and the corresponding background equivalent concentrations $\left[\mathrm{BEC}_{W J}=\right.$ $\left.Q_{W J}\left(\Delta \lambda_{a}\right) \times C_{I J}\right]$ and $\left[\operatorname{BEC}_{I J}\left(\lambda_{a}\right)=Q_{I J}\left(\lambda_{a}\right) \times C_{I J}\right]$.

2.2. Reagents and Test Solutions. Reagents of highest purity grade were used: $30 \% \mathrm{HCl}$ and $65 \% \mathrm{HNO}_{3}, 30 \% \mathrm{HF}, \mathrm{H}_{3} \mathrm{BO}_{3}$ (Suprapur, Merck), and tri-distilled water from quartz apparatus. The stock solutions of the analytes $\mathrm{Zn}, \mathrm{Cd}, \mathrm{Sb}, \mathrm{Cu}, \mathrm{Mn}$, $\mathrm{Pb}, \mathrm{Sn}, \mathrm{Cr}, \mathrm{U}$, and $\mathrm{Ba}\left(1 \mathrm{mg} \mathrm{mL}^{-1}\right)$ were prepared by using Merck Titrisol. The stock solutions of the matrix components $\mathrm{Al}, \mathrm{Ca}, \mathrm{Fe}, \mathrm{Mg}$, and $\mathrm{Ti}\left(10 \mathrm{mg} \mathrm{mL}^{-1}\right)$ were prepared by dissolving the corresponding high purity chlorides with a purity of $99.9999 \%$ in hydrochloric acid. The possible presence of impurities causes an uncertainty when the matrix concentration of $2 \mathrm{mg} \mathrm{mL}^{-1}$ is used. The $Q$ values were measured by using the following test solutions: $10 \mu \mathrm{g} \mathrm{mL}^{-1}$ for each of analytes and $2 \mathrm{mg} \mathrm{mL}^{-1}$ for each of interferents, separately. Plastic or PTFE ware was used throughout.

2.3. Certified Reference Materials. The International Atomic Energy Agency (Austria) IAEA/Soil 7-soil reference material, prepared from the fraction which passed through a $70 \mu \mathrm{m}$ sieve; the National Water Research Institute (NWRI) fortified water for trace elements, TMDA-51.2; NWRI, prepared from Lake Ontario water, filtered, diluted, and preserved with $0.2 \%$ nitric acid were used.

2.4. Sampling. Soil samples were collected in accordance with ISO 10381-2, soil quality sampling [55]. The samples were collected from a nonpolluted region which was found at a distance of about $8 \mathrm{~km}$ of the metallurgical factory for nonferrous metals in order to show the possibilities of the present ICP-OES method in the determination of low concentration of the pollutants in the presence of $\mathrm{Al}, \mathrm{Ca}, \mathrm{Fe}$, $\mathrm{Mg}$, and Ti as matrix constituents.

\subsection{Digestion Procedures}

2.5.1. Extraction of Trace Elements Soluble in Aqua Regia [27]. Extraction of trace elements soluble in aqua regia was used as a decomposition method in accordance with ISO 11466. A one g sample was weighed accurately in a reaction vessel; $0.5 \mathrm{~mL}$ of tri-distilled water was added to obtain slurry, followed by $9 \mathrm{~mL}$ of $\mathrm{HCl}\left(12 \mathrm{moL} \mathrm{L}^{-1}\right)$ and $3 \mathrm{~mL}$ nitric acid $\left(15.8 \mathrm{moL} \mathrm{L}^{-1}\right)$. Then, $10 \mathrm{~mL}$ of $0.5 \mathrm{moL} \mathrm{L}^{-1}$ nitric acid was added to the reaction vessel which was connected to the reflux condenser. The apparatus was placed on the top of the reaction vessel. The samples were allowed to stay for $16 \mathrm{~h}$ at room temperature for slow oxidation of the organic matter and reduction of the gases produced during the subsequent heating cycle. They were boiled under reflux for $2 \mathrm{~h}$ and allowed to cool slowly to room temperature. The content of the reaction vessel was transferred quantitatively to a $50 \mathrm{~mL}$ graduated flask and filled up to the mark with nitric acid $\left(0.5 \mathrm{moL} \mathrm{L}^{-1}\right)$. After the insoluble material has been settled, the supernatant solution was subjected to analysis by ICPOES. A blank sample containing the acids used for digestion was prepared in the same way. By this procedure, the silicate matrix was separated from the final sample solution.

2.5.2. Digestion Procedure with $\mathrm{HCl}-\mathrm{HNO}_{3}$ - $\mathrm{HF}$ in a Microwave System [28]. The digestion was performed in a microwave digestion system (Milestone 1200 , USA) at $230^{\circ} \mathrm{C}$ and at pressure of 70 bar. $0.5 \mathrm{~g}$ sample was weighed in a PTFE vessel. The digestion procedure in three steps was used: 1 st $-4 \mathrm{~mL}$ nitric acid (65\%) and $1 \mathrm{~mL}$ hydrochloric acid (30\%); 2nd-1 mL hydrofluoric acid (40\%) for complete dissolution of the sample; $3 \mathrm{rd}-10 \mathrm{~mL}$ boric acid, saturated at $20^{\circ} \mathrm{C}$ for complexing insoluble fluorides. Afterwards, boric acid (in excess to HF) was added in order to bind the HF as a $\mathrm{HBF}_{4}$ complex. $\mathrm{HBF}_{4}$ solutions do not etch glassware used (volumetric flasks, etc.) as well as the conventional ICP sample introduction system (glass nebulizer, glass chamber, and silica ICP-torch). So a conventional ICP-OES sample introduction system was used for the analysis of such solutions. The duration of one digestion step, including cooling period, was $40 \mathrm{~min}$. The final sample solution was $50 \mathrm{~mL}$. The concentration of boron in the sample solution was $1400 \mu \mathrm{g} \mathrm{mL}^{-1}$ and silicon-1870 $\mu \mathrm{g} \mathrm{mL}^{-1}$.

\section{Results and Discussion}

3.1. Database of Q Values and Detection Limits in Pure Solvent Obtained at $T_{\text {exc }} \approx 7200 \mathrm{~K}$. Table 2 lists the investigated prominent lines of $\mathrm{Zn}, \mathrm{Cd}, \mathrm{Sb}, \mathrm{Cu}, \mathrm{Mn}, \mathrm{Pb}, \mathrm{Sn}, \mathrm{Cr}, \mathrm{U}$, and $\mathrm{Ba}$ by $40.68 \mathrm{MHz}$ and spectrometer with high resolution. 
TABLE 2: Quantitative values for line interferences $\left[Q_{I J}\left(\lambda_{a}\right)\right]$ and wing background interference $\left[Q_{W J}\left(\Delta \lambda_{a}\right)\right]$ in the determination of trace of elements $\mathrm{Zn}, \mathrm{Cd}, \mathrm{Sb}, \mathrm{Cu}, \mathrm{Mn}, \mathrm{Pb}, \mathrm{Sn}, \mathrm{Cr}, \mathrm{U}$, and $\mathrm{Ba}$. Interferents: $\mathrm{Al}, \mathrm{Ca}, \mathrm{Fe}, \mathrm{Mg}$, and $\mathrm{Ti}$. The data listed under the wavelength of the prominent lines refer to background equivalent concentrations in pure solvent (BEC) and detection limits in pure solvent $\left(C_{L}\right)$.

\begin{tabular}{|c|c|c|c|}
\hline $\begin{array}{l}\text { Analytes, wave lengths, } \\
\lambda \mathrm{nm}\end{array}$ & Interferents & $Q_{W J}\left(\lambda_{a}\right)$ & $Q_{I J}\left(\lambda_{a}\right)$ \\
\hline \multirow{5}{*}{$\begin{array}{l}\text { Zn I } 213.856 \\
\mathrm{BEC}=0.05 \mu \mathrm{g} \mathrm{mL}^{-1} \\
C_{L}=1.4 \mathrm{ng} \mathrm{mL}^{-1}\end{array}$} & $\mathrm{Al}$ & $8.0 \times 10^{-6}$ & 0 \\
\hline & $\mathrm{Ca}$ & $2.0 \times 10^{-6}$ & 0 \\
\hline & $\mathrm{Fe}$ & 0 & $1.0 \times 10^{-5}$ \\
\hline & $\mathrm{Mg}$ & 0 & 0 \\
\hline & $\mathrm{Ti}$ & $2.0 \times 10^{-6}$ & 0 \\
\hline \multirow{5}{*}{$\begin{array}{l}\mathrm{Zn} \mathrm{II} 202.548 \\
\mathrm{BEC}=0.06 \mu \mathrm{g} \mathrm{mL}^{-1} \\
\mathrm{C}_{\mathrm{L}}=1.7 \mathrm{ng} \mathrm{\textrm {mL } ^ { - 1 }}\end{array}$} & $\mathrm{Al}$ & $2.0 \times 10^{-5}$ & 0 \\
\hline & $\mathrm{Ca}$ & $1.0 \times 10^{-6}$ & 0 \\
\hline & $\mathrm{Fe}$ & $1.0 \times 10^{-5}$ & 0 \\
\hline & $\mathrm{Mg}$ & $4.0 \times 10^{-6}$ & 0 \\
\hline & $\mathrm{Ti}$ & $2.0 \times 10^{-5}$ & 0 \\
\hline \multirow{5}{*}{$\begin{array}{l}\text { Cd II } 226.502 \\
\mathrm{BEC}=0.05 \mu \mathrm{g} \mathrm{mL}^{-1} \\
C_{L}=1.4 \mathrm{ng} \mathrm{mL}^{-1}\end{array}$} & $\mathrm{Al}$ & 0 & 0 \\
\hline & $\mathrm{Ca}$ & $1.3 \times 10^{-6}$ & 0 \\
\hline & $\mathrm{Fe}$ & $2.0 \times 10^{-5}$ & $8.0 \times 10^{-5}$ \\
\hline & $\mathrm{Mg}$ & 0 & 0 \\
\hline & $\mathrm{Ti}$ & $8.0 \times 10^{-5}$ & 0 \\
\hline \multirow{5}{*}{$\begin{array}{l}\text { Cd II } 214.438 \\
\text { BEC }=0.06 \mu \mathrm{g} \mathrm{mL}^{-1} \\
C_{\mathrm{L}}=1.7 \mathrm{ng} \mathrm{mL}^{-1}\end{array}$} & $\mathrm{Al}$ & 0 & 0 \\
\hline & $\mathrm{Ca}$ & $1.3 \times 10^{-6}$ & 0 \\
\hline & $\mathrm{Fe}$ & $6.2 \times 10^{-6}$ & $2.0 \times 10^{-5}$ \\
\hline & $\mathrm{Mg}$ & o & o \\
\hline & $\mathbf{T i}$ & $8.0 \times 10^{-5}$ & 0 \\
\hline \multirow{5}{*}{$\begin{array}{l}\text { Sb I } 206.838 \\
\text { BEC }=0.35 \mu \mathrm{g} \mathrm{mL}^{-1} \\
C_{\mathrm{L}}=10.0 \mathrm{ng} \mathrm{\textrm {mL } ^ { - 1 }}\end{array}$} & $\mathrm{Al}$ & $4.0 \times 10^{-4}$ & 0 \\
\hline & $\mathrm{Ca}$ & $3.0 \times 10^{-4}$ & 0 \\
\hline & $\mathrm{Fe}$ & $6.0 \times 10^{-5}$ & 0 \\
\hline & $\mathrm{Mg}$ & $1.0 \times 10^{-4}$ & o \\
\hline & $\mathrm{Ti}$ & $4.0 \times 10^{-4}$ & $1.0 \times 10^{-4}$ \\
\hline \multirow{5}{*}{$\begin{array}{l}\text { Cu I } 324.754 \\
\text { BEC }=0.045 \mu \mathrm{g} \mathrm{mL}^{-1} \\
C_{L}=1.3 \mathrm{ng} \mathrm{mL}^{-1}\end{array}$} & $\mathrm{Al}$ & o & $\mathbf{0}$ \\
\hline & $\mathrm{Ca}$ & 0 & 0 \\
\hline & $\mathrm{Fe}$ & 0 & 0 \\
\hline & $\mathrm{Mg}$ & 0 & 0 \\
\hline & $\mathrm{Ti}$ & 0 & 0 \\
\hline \multirow{5}{*}{$\begin{array}{l}\text { Mn II } 257.610 \\
\text { BEC }=0.0047 \mu \mathrm{g} \mathrm{mL}^{-1} \\
C_{\mathrm{L}}=0.13 \mathrm{ng} \mathrm{mL}^{-1}\end{array}$} & $\mathrm{Al}$ & 0 & 0 \\
\hline & $\mathrm{Ca}$ & 0 & 0 \\
\hline & $\mathrm{Fe}$ & 0 & 0 \\
\hline & $\mathrm{Mg}$ & 0 & 0 \\
\hline & $\mathbf{T i}$ & o & 0 \\
\hline \multirow{5}{*}{$\begin{array}{l}\text { Pb II } 220.353 \\
\text { BEC }=0.18 \mu \mathrm{g} \mathrm{mL}^{-1} \\
C_{\mathrm{L}}=5.0 \mathrm{ng} \mathrm{mL}^{-1}\end{array}$} & $\mathrm{Al}$ & $2.8 \times 10^{-4}$ & 0 \\
\hline & $\mathrm{Ca}$ & $1.0 \times 10^{-5}$ & 0 \\
\hline & $\mathrm{Fe}$ & $1.2 \times 10^{-4}$ & 0 \\
\hline & $\mathrm{Mg}$ & o & 0 \\
\hline & $\mathbf{T i}$ & 0 & 0 \\
\hline
\end{tabular}

TABLE 2: Continued.

\begin{tabular}{|c|c|c|c|}
\hline $\begin{array}{l}\text { Analytes, wave lengths, } \\
\lambda \mathrm{nm}\end{array}$ & Interferents & $Q_{W J}\left(\lambda_{a}\right)$ & $Q_{I J}\left(\lambda_{a}\right)$ \\
\hline \multirow{5}{*}{$\begin{array}{l}\text { Sn I } 283.999 \\
\text { BEC }=0.30 \mu \mathrm{g} \mathrm{mL}^{-1} \\
C_{L}=9.0 \mathrm{ng} \mathrm{mL}^{-1}\end{array}$} & Al & $1.7 \times 10^{-5}$ & 0 \\
\hline & $\mathrm{Ca}$ & $1.7 \times 10^{-5}$ & $\mathbf{0}$ \\
\hline & $\mathrm{Fe}$ & $2.8 \times 10^{-5}$ & $\mathbf{0}$ \\
\hline & Mg & $1.8 \times 10^{-4}$ & 0 \\
\hline & $\mathrm{Ti}$ & $3.0 \times 10^{-5}$ & 0 \\
\hline \multirow{5}{*}{$\begin{array}{l}\text { Cr II } 206.149 \\
\mathrm{BEC}=0.14 \mu \mathrm{g} \mathrm{mL}^{-1} \\
C_{L}=4.0 \mathrm{ng} \mathrm{mL}^{-1}\end{array}$} & $\mathrm{Al}$ & 0 & 0 \\
\hline & $\mathrm{Ca}$ & $5.2 \times 10^{-5}$ & 0 \\
\hline & $\mathrm{Fe}$ & $3.0 \times 10^{-5}$ & 0 \\
\hline & $\mathrm{Mg}$ & $4.0 \times 10^{-5}$ & 0 \\
\hline & $\mathrm{Ti}$ & $2.0 \times 10^{-5}$ & $3.0 \times 10^{-5}$ \\
\hline \multirow{5}{*}{$\begin{array}{l}\text { Cr II 267.716 } \\
\text { BEC }=0.08 \mu \mathrm{g} \mathrm{mL}^{-1} \\
C_{\mathrm{L}}=2.3 \mathrm{ng} \mathrm{mL}^{-1}\end{array}$} & Al & o & o \\
\hline & $\mathrm{Ca}$ & 0 & 0 \\
\hline & $\mathrm{Fe}$ & $7.5 \times 10^{-6}$ & 0 \\
\hline & Mg & o & 0 \\
\hline & $\mathrm{Ti}$ & $\mathbf{0}$ & $\mathbf{0}$ \\
\hline \multirow{5}{*}{$\begin{array}{l}\text { U II } 385.958 \\
\mathrm{BEC}=0.05 \mu \mathrm{g} \mathrm{mL}^{-1} \\
C_{L}=1.4 \mathrm{ng} \mathrm{mL}^{-1}\end{array}$} & $\mathrm{Al}$ & 0 & 0 \\
\hline & $\mathrm{Ca}$ & $5.0 \times 10^{-5}$ & 0 \\
\hline & $\mathrm{Fe}$ & $5.2 \times 10^{-4}$ & $6.2 \times 10^{-4}$ \\
\hline & $\mathrm{Mg}$ & $7.0 \times 10^{-5}$ & 0 \\
\hline & $\mathrm{Ti}$ & $5.5 \times 10^{-5}$ & 0 \\
\hline \multirow{5}{*}{$\begin{array}{l}\text { U II } 367.007 \\
\mathrm{BEC}=0.05 \mu \mathrm{g} \mathrm{mL}^{-1} \\
C_{L}=1.4 \mathrm{ng} \mathrm{mL}^{-1}\end{array}$} & $\mathrm{Al}$ & 0 & 0 \\
\hline & $\mathrm{Ca}$ & $5.0 \times 10^{-5}$ & 0 \\
\hline & $\mathrm{Fe}$ & $5.0 \times 10^{-5}$ & $6.0 \times 10^{-4}$ \\
\hline & $\mathrm{Mg}$ & $7.0 \times 10^{-5}$ & 0 \\
\hline & $\mathrm{Ti}$ & $5.5 \times 10^{-5}$ & 0 \\
\hline \multirow{5}{*}{$\begin{array}{l}\text { U II } 263.553 \\
\text { BEC }=0.09 \mu \mathrm{g} \mathrm{mL}^{-1} \\
C_{L}=2.6 \mathrm{ng} \mathrm{mL}^{-1}\end{array}$} & $\mathrm{Al}$ & $5.0 \times 10^{-5}$ & 0 \\
\hline & $\mathrm{Ca}$ & 0 & 0 \\
\hline & $\mathrm{Fe}$ & $1.0 \times 10^{-4}$ & $5.0 \times 10^{-4}$ \\
\hline & $\mathrm{Mg}$ & 0 & 0 \\
\hline & $\mathrm{Ti}$ & $1.0 \times 10^{-4}$ & $5.0 \times 10^{-3}$ \\
\hline \multirow{5}{*}{$\begin{array}{l}\text { U II } 409.014 \\
\text { BEC }=0.20 \mu \mathrm{g} \mathrm{mL}^{-1} \\
\mathrm{C}_{\mathrm{L}}=6.1 \mathrm{ng} \mathrm{mL}^{-1}\end{array}$} & Al & $1.0 \times 10^{-4}$ & o \\
\hline & $\mathrm{Ca}$ & o & 0 \\
\hline & $\mathrm{Fe}$ & 0 & 0 \\
\hline & Mg & 0 & 0 \\
\hline & $\mathrm{Ti}$ & 0 & 0 \\
\hline \multirow{5}{*}{$\begin{array}{l}\text { Ba II } 455.403 \\
\text { BEC }=0.0042 \mu \mathrm{g} \mathrm{mL}^{-1} \\
C_{L}=0.12 \mathrm{ng} \mathrm{mL}^{-1}\end{array}$} & Al & 0 & 0 \\
\hline & $\mathrm{Ca}$ & $\mathbf{0}$ & 0 \\
\hline & $\mathrm{Fe}$ & 0 & 0 \\
\hline & Mg & 0 & 0 \\
\hline & $\mathrm{Ti}$ & 0 & 0 \\
\hline
\end{tabular}

If the selected analysis line is the most prominent line in accordance with the Boumans ICP Tables [56], this line was investigated only, this refers to the following elements: $\mathrm{Sb}, \mathrm{Cu}$, $\mathrm{Mn}, \mathrm{Pb}, \mathrm{Sn}$, and $\mathrm{Ba}$. If the selected analysis line is not the most prominent line, the lines located before the selected analysis line were listed also, in the cases of $\mathrm{Zn}, \mathrm{Cd}, \mathrm{Cr}$, and $\mathrm{U}$. The data given underneath the wavelength of the analysis lines 
corresponds to detection limits in pure solvent calculated by (2) [48]:

$$
C_{L}=2 \sqrt{2} \times 0.01 \times \mathrm{RSDB} \times \mathrm{BEC} .
$$

This equation is written in terms of the background equivalent concentration in pure solvent $(\mathrm{BEC})$ and relative standard deviation of the background $(\mathrm{RSDB}=1 \%)$ [48]. The selected prominent lines in the presence of complex matrix are printed in bold.

The results show that in the determination of trace of elements in environmental samples by means of $40.68 \mathrm{MHz}$ ICP and spectrometer with high resolution, the prominent lines of the elements $\mathrm{Zn}, \mathrm{Cd}, \mathrm{Sb}, \mathrm{Cu}, \mathrm{Mn}, \mathrm{Pb}, \mathrm{Sn}, \mathrm{Cr}, \mathrm{U}$, and Ba, which are free of line interferences, can be selected as analysis lines. The following exceptions are observed in the case of Cd II $214.438 \mathrm{~nm}$ where $\left[Q_{I \mathrm{Fe}}\left(\lambda_{a}\right)>0\right]$ and Sb I $206.838 \mathrm{~nm}$ where $\left[Q_{I \mathrm{Ti}}\left(\lambda_{a}\right)>0\right]$. It is well known that the magnitude of spectral interferences depends on the spectral resolution [36], but the selected "best" analysis lines are the same, irrespective of ICP and operating conditions, and therefore, these data can be transferred from one ICP system to another [44].

The magnitude of line and wing background interferences by $40.68 \mathrm{MHz}$ and spectrometer with high resolution are significantly lower in comparison with the corresponding values obtained by $27.12 \mathrm{MHz}$ ICP and spectrometer with middle resolution (practical spectral bandwidth $=15.6 \mathrm{pm}$ ) [57]. This result can be expected, but the differences between the magnitudes of the $Q$-values cannot be predicted in general terms, and consequently, they have to be estimated only by systematic experimental results.

With respect to the "zero" values of the $\left[Q_{I J}\left(\lambda_{a}\right)\right]$, we will note the following in accordance with [48]: if in Table 2 the $\left[Q_{I J}\left(\lambda_{a}\right)\right]$ is listed as "zero," this implies that $\left[Q_{I J}\left(\lambda_{a}\right) \times\right.$ $\left.C_{I J}\right]$ is equal to or smaller than the numerical values of the detection limits (in $\mathrm{ng} \mathrm{mL}^{-1}$ ) shown in Table 2 underneath the corresponding prominent line. The database of [Q-values] from Table 2 can be used for the following calculations:

(i) true detection limits in the case of a multicomponent matrix by using (3) [48]:

$$
C_{L, \text { true }}=\frac{2}{5} \Sigma_{J} Q_{I J}\left(\lambda_{a}\right) \times C_{I J}+C_{L, \text { conv }},
$$

where

$$
\begin{aligned}
C_{L, \text { conv }}= & 2 \sqrt{2} \times 0.01 \times \mathrm{RSDBL} \\
& \times\left[\mathrm{BEC}+\Sigma_{J} \mathrm{Q}_{I J}\left(\lambda_{a}\right) \times C_{I J}+\Sigma_{J} \mathrm{Q}_{W J}\left(\Delta \lambda_{a}\right) \times C_{I J}\right] .
\end{aligned}
$$

Therefore, the true detection limit $\left(C_{L, \text { true }}\right)$ is defined by (5):

$$
\begin{aligned}
C_{L, \text { true }}= & \frac{2}{5} \Sigma_{J} Q_{I J}\left(\lambda_{a}\right) \times C_{I J}+2 \sqrt{2} \times 0.01 \times \mathrm{RSDB} \\
& \times\left[\mathrm{BEC}+\Sigma_{J} Q_{I J}\left(\lambda_{a}\right) \times C_{I J}+\Sigma_{J} \mathrm{Q}_{W J}\left(\Delta \lambda_{a}\right) \times C_{I J}\right] ;
\end{aligned}
$$

\begin{tabular}{|c|c|c|}
\hline \multirow[t]{2}{*}{ Analytes lines $\lambda, \mathrm{nm}$} & \multicolumn{2}{|c|}{$\begin{array}{c}\text { Interferent concentration } C_{I J},\left(\mu \mathrm{g} \mathrm{mL}^{-1}\right) \\
\text { for which } Q_{I J}\left(\lambda_{a}\right)=0\end{array}$} \\
\hline & $\mathrm{Fe}$ & $\mathrm{Ti}$ \\
\hline Zn I 213.856 & 140 & 350 \\
\hline Zn II 202.548 & - & - \\
\hline Cd II 226.502 & 18 & - \\
\hline Cd II 214.438 & 85 & - \\
\hline Sb I 206.838 & - & 100 \\
\hline Cr II 205.552 & 150 & - \\
\hline Cr II 206.149 & - & 133 \\
\hline Cr II 267.716 & - & - \\
\hline U II 385.958 & 2.0 & - \\
\hline U II 367.007 & 2.0 & - \\
\hline U II 263.553 & 5.0 & 1.2 \\
\hline U II 409.014 & - & - \\
\hline
\end{tabular}

TABLE 3: Interferent concentration $C_{I J}\left(\mu \mathrm{g} \mathrm{mL}^{-1}\right)$ for which $\left[Q_{I J}\left(\lambda_{a}\right)\right.$ $=0]$ in the presence of $\mathrm{Fe}$ or $\mathrm{Ti}$ as interferents for the elements: $\mathrm{Zn}$, $\mathrm{Cd}, \mathrm{Sb}, \mathrm{Cr}$, and $\mathrm{U}$.

(ii) maximal interferent concentration $C_{I J}$ for which $\left[Q_{I J}\left(\lambda_{a}\right)=0\right]$ in the presence of matrix constituents is given by the next equations [48]:

$$
\begin{gathered}
S_{I J}\left(\lambda_{a}\right) \times C_{I J}=S_{A} \times C_{L} . \\
C_{I J}=\frac{C_{L}}{Q_{I J}\left(\lambda_{a}\right)} .
\end{gathered}
$$

The maximal interferent concentration $C_{I J}$ for which $\left[Q_{I J}\left(\lambda_{a}\right)=0\right]$ in the presence of iron or titanium as interferents (7) for the most prominent lines with $\left[Q_{I J}\left(\lambda_{a}\right)>\right.$ $0]$ is listed in Table 3. These matrix constituents determine line interference levels around the most prominent lines of $\mathrm{Zn}, \mathrm{Cd}, \mathrm{Sb}, \mathrm{Cr}$, and $\mathrm{U}$ in accordance with Table 2 . The selected prominent lines are printed in bold. If the concentration of the interferents in the sample solution is lower in comparison to the corresponding values shown in Table 3 , the most prominent lines can be used as analysis lines.

Therefore, Table 3 can be used for additional line selection. In the determination of pollutants in water samples, the most prominent lines in accordance with Table 3 can be used, regarding the concentrations of iron and titanium in the different type of investigated water sample.

In conclusion of Section 3.1, we have to note that by using the selected analysis lines, the lowest possible detection limits can be achieved in the determination of the above mentioned trace elements in soil and similar materials by using one of the present day ICP-OES equipment. The quantification of all significant interferences for the most prominent lines ensures the accuracy of measurements by ICP-OES. On the other hand, we can use all prominent lines as analysis lines, but the detection limits will be higher. The increasing of the detection limits depends on the magnitude of the line interference levels and the concentration of the matrix elements in the final sample solutions (5). 
Here, we have to note that the quantitative information for the spectral interferences in the presence of $\mathrm{Al}, \mathrm{Ca}, \mathrm{Fe}$, $\mathrm{Mg}$, and $\mathrm{Ti}$ as matrix constituents in the determination $\mathrm{Hg}$, As, Se, Tl, Sn, and Bi as well as $\mathrm{Pt}, \mathrm{Pd}$, and $\mathrm{Rh}$ by $40.68 \mathrm{MHz}$ ICP and optical emission spectrometer with high resolution under the same experimental conditions is given in $[16,18]$.

\subsection{Experimental Demonstration of the Q-Concepts and HR-} ICP-OES in the Analysis of Environmental Materials. The focus of this section is on recent applications, illustrating the versatility of the $Q$-concept and ICP-OES in the determination of toxic elements in environmental samples.

\subsubsection{Soil Samples}

(1) Determination of Trace Elements in Certified Reference Materials IAEA/Soil 7. Both decomposition procedures: extraction of trace elements soluble in aqua regia and complex digestion procedure with $\left(\mathrm{HCl}-\mathrm{HNO}_{3}-\mathrm{HF}\right)$ in a microwave system were used as described in (Section 2.5). The present paper offers a methodology which includes two steps.

(i) Determination of Major Elements in the Final Sample Solutions.

(a) Decomposition procedure in the presence of aqua regia (in $\mu \mathrm{g} \mathrm{mL}^{-1}$ ): $\mathrm{Al}-660 \pm 6 ; \mathrm{Ca}-3160 \pm 25, \mathrm{Fe}-500 \pm$ $6, \mathrm{Mg}-210 \pm 5$, and $\mathrm{Ti}-9.6 \pm 0.5$.

(b) Decomposition procedure in the presence of $(\mathrm{HCl}$ $\mathrm{HNO}_{3}-\mathrm{HF}$ ) (in $\mu \mathrm{g} \mathrm{mL}^{-1}$ ): $\mathrm{Al}-936 \pm 8$; $\mathrm{Ca}-3265 \pm 16$; $\mathrm{Fe}-514 \pm 6 ; \mathrm{Mg}-225 \pm 5 ; \mathrm{Ti}-58 \pm 2$.

Mean values for statistical confidence $P=95 \%$ and six replicates $(n=6)$ are obtained. The selected prominent lines, which are free of interelement interferences, and $\mathrm{OH}$ band are used. The results show that the concentrations of $\mathrm{Ca}, \mathrm{Fe}$, and $\mathrm{Mg}$ in the certified reference material IAEA/Soil 7 do not depend significantly on the dissolution procedure. The concentration of $\mathrm{Al}$ and $\mathrm{Ti}$ is lower by using aqua regia extraction procedure in comparison with the dissolution procedure with HF. The final sample solutions that contain in both cases high solute matrix concentrations and spectral interferences in the determination of traces of hazardous waste elements by ICP-OES should be taken into consideration, that is, the selected analysis lines can be used as shown in Table 2. The determination of matrix elements is needed for additional line selection in accordance with Table 3 and for calculation of true detection limits (5).

(ii) Determination of $\mathrm{Zn}, \mathrm{Cd}, \mathrm{Cu}, \mathrm{Mn}, \mathrm{Pb}, \mathrm{Cr}, \mathrm{U}$, and $\mathrm{Ba}$. The content of $\mathrm{Zn}, \mathrm{Sb}, \mathrm{Cd}, \mathrm{Cu}, \mathrm{Mn}, \mathrm{Pb}, \mathrm{Cr}, \mathrm{U}$, and $\mathrm{Ba}$ obtained by Jobin Yvon ULTIMA 2 in the analysis of certified reference material IAEA/Soil 7 is presented in Table 4. Both digestion procedures: with aqua regia (column 2) and with $(\mathrm{HCl}-$ $\mathrm{HNO}_{3}-\mathrm{HF}$ ) (column 5) described in Section 2.5 are used. The mean values $X$ for $n=4$ replicates and the confidence interval of the mean value $\Delta X$ for statistical confidence $P=95 \%$ and $f=n-1=3$ (columns 2 and 4 ) and the relative standard deviations (RSD\%) (columns 3 and 5) are calculated. The certified values of the reference material IAEA/Soil 7 are given for comparison (column 6). Using Student's criterion [58], no statistical differences between the experimental values (columns 2 and 4) and certified values (column 6) were registered, and by this way the accuracy can be ensured, independent of the dissolution procedures either by extraction of trace elements soluble in aqua regia or dissolution of the sample with $\mathrm{HCl}-\mathrm{HNO}_{3}$ $\mathrm{HF}$ in a microwave system. There, we have to note that the final sample solution by using digestion procedure with $\mathrm{HCl}$ $\mathrm{HNO}_{3}-\mathrm{HF}$ contains $\mathrm{Si}$ and $\mathrm{B}$, but the selected prominent lines of the analytes were free from both line and wing background interferences in the presence of these elements as interferents.

(iii) Detection Limits with respect to Dissolved Solids and Threshold Concentrations. Table 5 presents the following data: the threshold concentrations of $\mathrm{Zn}, \mathrm{Sb}, \mathrm{Cd}, \mathrm{Cu}, \mathrm{Mn}, \mathrm{Pb}, \mathrm{Cr}$, $\mathrm{U}$, and $\mathrm{Ba}$ in soil $\left(\mu \mathrm{g} \mathrm{g}^{-1}\right)$, in accordance with the regulation Number 3 from the Ministry of Environment and Water of Bulgaria, [29] (column 2); the maximum permissible concentrations of potentially toxic elements in sludge-treated soils $\left(\mu \mathrm{gg}^{-1}\right.$ for dry soil) in EC member states and US [30] (column 3); the maximum permissible concentrations for uranium [31] (column 4); and the true detection limits $\left(C_{L \text {,true }}\right)$ obtained by the present ICP-OES method $\left(\mu \mathrm{g} \mathrm{g}^{-1}\right)$, which were calculated by (4) and (5) in the determination of above mentioned elements in the certified reference material IAEA/Soil 7 (column 5).

The results show that the obtained true detection limits by using the selected analysis lines and operating conditions listed in Table 1 are significantly lower in comparison with the maximum permissible limits. Therefore, the level of pollution can be estimated in accordance to the existing maximum permissible limits.

(2) Determination of Trace Elements in Soil Sample. As an example in Table 6, the contents of $\mathrm{Zn}, \mathrm{Cr}, \mathrm{Pb}$, and $\mathrm{Cu}$ are presented in soil sample, collected in accordance with Section 2.4 [55] from relatively nonpolluted region in order to show the possibilities of the present ICP-OES method in the determination of low concentration of pollutants in the presence of $\mathrm{Al}, \mathrm{Ca}, \mathrm{Fe}, \mathrm{Mg}$, and $\mathrm{Ti}$ as matrix constituents. Extraction of trace elements soluble in aqua regia was used as a decomposition method (Section 2.5) [27].

We have to note that aqua regia will not totally dissolve soil and similar materials and efficiency of extraction for particular elements can differ for various types of soil. For estimation of the accuracy of results, the direct current arc method (D.C. Arc-OES) was used as an independent method for analysis of solid sample (column 4). The specifications of the spectrograph, D.C. power generator, and operating conditions are shown in [57]. Using Student's criterion [58], statistical differences between the results obtained by the ICPOES and D.C. Arc-OES are not observed.

(3) Determination of $\mathrm{Cr}, \mathrm{Sb}, \mathrm{Zn}, \mathrm{Pb}, \mathrm{Cd}, \mathrm{Mn}, \mathrm{Cu}, \mathrm{U}$, and $\mathrm{Ba}$ in National Water Research Institute (NWRI) Water Certified Standard, TMDA-51.2. Heavy metal contaminations can pose 
TABLE 4: Content of $\mathrm{Zn}, \mathrm{Sb}, \mathrm{Cd}, \mathrm{Cu}, \mathrm{Mn}, \mathrm{Pb}, \mathrm{Cr}, \mathrm{U}$, and $\mathrm{Ba}\left(\right.$ in $\left.\mu \mathrm{g} \mathrm{g}^{-1}\right)$ obtained by JY ULTIMA 2 in the analysis certified reference material IAEA/Soil 7 by both procedures with aqua regia [27] (column 2) and with ( $\left.\mathrm{HCl}-\mathrm{HNO}_{3}-\mathrm{HF}\right)$ [28] (column 5): mean values $X$ for $(n=4$ replicates) and the confidence interval of the mean value $\Delta X$ for statistical confidence $P=95 \%$ and $f=n-1=3$ (columns 2 and 4 ) and relative standard deviations (RSD \%) (columns 3 and 5), and certified values (column 6).

\begin{tabular}{|c|c|c|c|c|c|}
\hline \multirow{2}{*}{ Selected prominent lines, $\lambda$, nm } & \multicolumn{2}{|c|}{ Procedure with aqua regia } & \multicolumn{2}{|c|}{ Procedure with $\left(\mathrm{HCl}-\mathrm{HNO}_{3}-\mathrm{HF}\right)$} & \multirow{2}{*}{$\begin{array}{l}\text { Certified values. Concentration in } \\
\qquad\left(\mu \mathrm{gg}^{-1}\right)\end{array}$} \\
\hline & $\begin{array}{c}\text { Concentration in }\left(\mu \mathrm{gg}^{-1}\right) \\
\qquad X \pm \Delta X\end{array}$ & $\mathrm{RSD} \%$ & $\begin{array}{c}\text { Concentration in }\left(\mu \mathrm{gg}^{-1}\right) \\
\qquad X \pm \Delta X\end{array}$ & RSD \% & \\
\hline Zn II 202.548 & $103.00 \pm 1.4$ & 1.4 & $104.00 \pm 1.4$ & 1.4 & 104 \\
\hline Sb I 206.838 & $1.65 \pm 0.05$ & 3.0 & $1.72 \pm 0.04$ & 2.3 & 1.7 \\
\hline Cd II $214.438^{*}$ & $1.27 \pm 0.06$ & 4.7 & $1.30 \pm 0.06$ & 4.7 & $1.3^{*}$ \\
\hline Cu I 324.754 & $11.00 \pm 0.4$ & 3.6 & $10.60 \pm 0.4$ & 3.8 & 11.0 \\
\hline Mn II 257.610 & $632.80 \pm 13$ & 2.0 & $627.60 \pm 13.0$ & 2.0 & 631 \\
\hline Pb II 220.353 & $59.80 \pm 1.2$ & 2.0 & $60.00 \pm 1.0$ & 1.7 & 60.0 \\
\hline Cr II 267.716 & $59.00 \pm 1.6$ & 2.6 & $58.00 \pm 1.8$ & 3.1 & 60.0 \\
\hline U II 409.014 & $2.62 \pm 0.1$ & 3.8 & $2.56 \pm 0.1$ & 3.9 & 2.6 \\
\hline Ba II $455.403^{*}$ & $162.00 \pm 5.0$ & 3.0 & $162.00 \pm 5.0$ & 3.0 & $159^{*}$ \\
\hline
\end{tabular}

${ }^{*}$ Noncertified information value.

TABLE 5: Threshold concentrations in the determination of $\mathrm{Zn}, \mathrm{Sb}, \mathrm{Cd}, \mathrm{Cu}, \mathrm{Mn}, \mathrm{Pb}, \mathrm{Cr}, \mathrm{U}$, and Ba in soil ( $\left.\mu \mathrm{gg}^{-1}\right)$ [29] (column 2) and the maximum permissible concentrations of potentially toxic elements in sludge-treated soils ( $\mu \mathrm{g} \mathrm{g}^{-1}$ dry soil) in EC member states and US [30] (column 3), maximum permissible concentrations for U [31] (column 4), and true detection limits obtained by the present ICP-OES method $\left(\mu \mathrm{g} \mathrm{g}^{-1}\right)$ (column 5).

\begin{tabular}{|c|c|c|c|c|}
\hline $\begin{array}{l}\text { Selected prominent } \\
\text { lines, wavelength } \\
\lambda, \mathrm{nm}\end{array}$ & $\begin{array}{c}\text { Threshold concentrations for } \\
\text { soils, }\left(\mu \mathrm{g} \mathrm{g}^{-1}\right) \text { Bulgarian } \\
\text { legislation } \\
{[29]}\end{array}$ & $\begin{array}{c}\text { Maximum permissible } \\
\text { concentrations in } \\
\text { sludge-treated soils (in } \mu \mathrm{g} \mathrm{g}^{-1} \text { ) } \\
\text { in EU member states [30] }\end{array}$ & $\begin{array}{l}\text { Maximum permissible } \\
\text { concentration for } U \\
\quad\left(\text { in } \mu \mathrm{g} \mathrm{g}^{-1}\right)[31]\end{array}$ & $\begin{array}{c}\text { True detection limits } \\
\text { obtained by the present } \\
\text { ICP-OES method } \\
\left(\mu \mathrm{g} \mathrm{g}^{-1}\right)\end{array}$ \\
\hline Zn II 202.54 & $88 \div 180$ & $250 \div 300$ & no data & 0.12 \\
\hline Sb I 206.838 & no data* & no data & no data & 1.5 \\
\hline Cd II 214.438 & $0.4 \div 1.0$ & $1 \div 3$ & no data & 0.12 \\
\hline Cu I 324.754 & $34 \div 70$ & $100 \div 140$ & no data & 0.07 \\
\hline Mn II 257.610 & no data & no data & no data & 0.07 \\
\hline Pb II 220.353 & $26 \div 50$ & $80 \div 100$ & no data & 0.65 \\
\hline Cr II 267.716 & $65 \div 130$ & 200 & no data & 0.12 \\
\hline U II 409.014 & $34 \div 70$ & $100 \div 140$ & $0.3 \div 11.7$ & 0.75 \\
\hline Ba II 455.403 & no data & no data & no data & 0.06 \\
\hline
\end{tabular}

${ }^{*}$ The values are not given in the corresponding documents.

potential health concerns when detected in drinking water and in different aquatic environments [59-62]. The detection limits and the accuracy of analytical results are of prime importance. The European standard EN ISO 11855 “water quality determination of selected elements by inductively coupled plasma optical emission spectroscopy (ICP-OES)" offers a method for the determination of pollutants in drinking water [63]. It should be noted that the line interference level for the most prominent lines of $\mathrm{Zn}, \mathrm{Cu}, \mathrm{Pb}$, and $\mathrm{Mn}$ is determined from iron and titanium (Table 3). By using the information for the matrix interferences from ISO 11855 , the chemists cannot decide which of the prominent lines is appropriate as analysis line, without both the quantitative information for line interference level in the presence of iron and the concentration of iron in final sample solutions. The quantification of all significant interferences for selected prominent lines ensures the accuracy of measurements by a given ICP-OES system. The concentrations of iron in the final sample solution have to be known in advance or have to be determined previously as was mentioned above. If the concentration of iron in the sample solution is lower than the corresponding values shown in column 2 for the most prominent lines (Table 3 ), then these lines can be used as analysis line and lower detection limits can be achieved.

In the determination of $\mathrm{Cr}, \mathrm{Sb}, \mathrm{Zn}, \mathrm{Pb}, \mathrm{Cd}, \mathrm{Mn}, \mathrm{Cu}$, $\mathrm{U}$, and $\mathrm{Ba}$ in TMDA-51.2, the most prominent lines of $\mathrm{Cu}$, $\mathrm{Pb}, \mathrm{Ba}$, and $\mathrm{Mn}$ were free from line interference (Table 2). The most prominent lines of chromium (Cr II $205.552 \mathrm{~nm}$ ) and antimony (Sb I $206.838 \mathrm{~nm}$ ) were influenced by line interference from titanium, but in case of water samples, this element is not common $[64,65]$. The most prominent lines of zinc ( $\mathrm{Zn} \mathrm{I} 213.856 \mathrm{~nm}$ ), cadmium (Cd II 226. $502 \mathrm{~nm}$ ), uranium (U II $238.958 \mathrm{~nm}$ ), and chromium (Cr II $205.552 \mathrm{~nm}$ ) were influenced by line interference from iron 
TABLE 6: Determination of $\mathrm{Zn}, \mathrm{Cr}, \mathrm{Pb}$, and $\mathrm{Cu}$ in soil sample, obtained by ULTIMA 2: mean values $[X]$ for $(n=4$ replicates) and the confidence interval of the mean value $[\Delta X]$ for statistical confidence $P=95 \%$ and $f=n-1=3$ (column 2); relative standard deviation (RSD \%) (column 3). Columns 5 and 6 list the corresponding mean values $[\Delta X]$ for statistical confidence $P=95 \%$ and $f=n-1=3$ (column 5) and RSD, \%, obtained by D.C. Arc-OES.

\begin{tabular}{lcccc}
\hline & $\begin{array}{c}\text { ULTIMA 2, ICP-OES } \\
\text { Concentration, } X \pm \Delta X \\
\left(\mu \mathrm{gg}^{-1}\right)\end{array}$ & RSD, \% & $\begin{array}{c}\text { Selected prominent } \\
\text { line, wavelength, } \lambda, \mathrm{nm}\end{array}$ & $\begin{array}{c}\text { D.C. Arc-OES } \\
\text { Concentration, } X \pm \Delta X \\
\left(\mu \mathrm{g} \mathrm{g}^{-1}\right)\end{array}$ \\
\hline Zn II 202.548 & $77.5 \pm 1.2$ & 1.6 & Zn I 328.233 & $75 \pm 4.2$ \\
Cr II 267.716 & $54.0 \pm 1.0$ & 1.9 & Cr II 267.716 & $55.0 \pm 3.0$ \\
Pb II 220.353 & $22.0 \pm 0.5$ & 2.3 & Pb I 283.563 & 5.6 \\
Cu I 324.754 & $15.0 \pm 0.4$ & 2.7 & Cu I 324.754 & 5.5 \\
\hline
\end{tabular}

TABLE 7: Detection limits in pure solvent $C_{L}$ (column 2) obtained by ULTIMA 2 by using the most prominent lines of $\mathrm{Cr}, \mathrm{Sb}, \mathrm{Zn}, \mathrm{Pb}, \mathrm{Cd}, \mathrm{Mn}$, $\mathrm{Cu}, \mathrm{U}$, and $\mathrm{Ba}$ (column 1) under optimal experimental conditions (Table 1), threshold concentrations in accordance with Bulgarian Regulation No. 9 on the quality of water intended for human consumption [32] (column 3), mean values $[X]$ for $(n=4$ replicates), and the confidence interval of the mean value $[\Delta X]$ for statistical confidence $P=95 \%$ and $f=n-1=3$ (column 4) as well as the RSD (column 5) of the analytical results obtained by ICP-OES in the determination of $\mathrm{Cr}, \mathrm{Sb}, \mathrm{Zn}, \mathrm{Pb}, \mathrm{Cd}, \mathrm{Mn}, \mathrm{Cu}, \mathrm{U}$, and $\mathrm{Ba}$ in NWRI TMDA-51.2 (column 4). Column 6 shows the certified values.

\begin{tabular}{|c|c|c|c|c|c|}
\hline \multirow{2}{*}{$\begin{array}{l}\text { Most prominent lines, } \\
\text { wavelength, } \lambda, \mathrm{nm}\end{array}$} & \multirow{2}{*}{$C_{L}\left(\mathrm{ng} \mathrm{mL}^{-1}\right)$} & \multirow{2}{*}{$\begin{array}{l}\text { Threshold concentrations, } \\
\left(\mathrm{ng} \mathrm{mL} \mathrm{m}^{-1}\right) \text { in accordance } \\
\text { with regulation no. } 9\end{array}$} & \multicolumn{2}{|c|}{ ICP-OES ULTIMA 2} & \multirow{2}{*}{ Certified values, $\left(\mathrm{ng} \mathrm{mL} \mathrm{m}^{-1}\right)$} \\
\hline & & & $\begin{array}{c}\text { Concentrations, } \\
\left(\mathrm{ng} \mathrm{mL} \mathrm{mL}^{-1}\right)\end{array}$ & RSD, \% & \\
\hline Cr II 205.552 & 3.0 & 50 & $61.9 \pm 1.0$ & 1.6 & 62.5 \\
\hline Sb I 206.838 & 10 & 5.0 & $\begin{array}{l}\text { the element is not } \\
\text { detected }\end{array}$ & - & 3.1 \\
\hline Zn I 213.856 & 1.4 & 4000 & $105.5 \pm 1.5$ & 1.4 & 106 \\
\hline Pb II 220.353 & 5.0 & 10 & $73.0 \pm 1.0$ & 1.3 & 72.9 \\
\hline Cd II 226.502 & 1.4 & 5.0 & $25.0 \pm 0.5$ & 2.0 & 25.1 \\
\hline Mn II 257.610 & 0.13 & 50 & $81.8 \pm 1.2$ & 1.4 & 82.0 \\
\hline Cu I 324.754 & 1.3 & 2000 & $90.8 \pm 1.2$ & 1.3 & 91.0 \\
\hline U II 385.958 & 1.4 & 30 & $30.0 \pm 1.1$ & 3.3 & 29.3 \\
\hline Ba II 455.403 & 0.12 & no data & $73.0 \pm 1.0$ & 1.3 & 73.3 \\
\hline
\end{tabular}

$[64,65]$. The concentration of iron from TMDA-51.2 analysis certificate is $0.111 \mu \mathrm{g} \mathrm{mL}^{-1}$, which is lower than $140 \mu \mathrm{g} \mathrm{mL}^{-1}$ from Table 3 in the case of Zn I $213.856 \mathrm{~nm} ; 0.111 \mu \mathrm{g} \mathrm{mL}^{-1}<$ $18 \mu \mathrm{g} \mathrm{mL}^{-1}$ for Cd II $226.502 \mathrm{~nm} ; 0.111 \mu \mathrm{g} \mathrm{mL}^{-1}<2.0 \mu \mathrm{g} \mathrm{mL}^{-1}$ for U II $385.958 \mathrm{~nm} ; 0.111 \mu \mathrm{g} \mathrm{mL}^{-1}<150 \mu \mathrm{g} \mathrm{mL}^{-1}$ for Cr II $205.552 \mathrm{~nm}$. Hence, the most prominent lines of $\mathrm{Zn}, \mathrm{U}, \mathrm{Cr}$, and $\mathrm{Cd}$ can be used as analysis lines.

In Table 7, the detection limits are presented in pure solvent $C_{L}$ (column 2) obtained by ICP-OES, ULTIMA 2 by using the most prominent lines of $\mathrm{Cr}, \mathrm{Sb}, \mathrm{Zn}, \mathrm{Pb}, \mathrm{Cd}, \mathrm{Mn}, \mathrm{Cu}$, $\mathrm{U}$, and $\mathrm{Ba}$ under optimal experimental conditions (Table 1), threshold concentrations in accordance with the Bulgarian No. 9 on the Quality of Water Intended for Human Consumption from the Ministry of Environment and Water of Bulgaria [32] (column 3), mean values [X] for ( $n=4$ replicates), and the confidence interval of the mean value $[\Delta X]$ for statistical confidence $P=95 \%$ and $f=n-1=3$ (column 4 ) as well as the RSD (column 5) of the analytical results obtained by ICPOES in the determination of $\mathrm{Cr}, \mathrm{Sb}, \mathrm{Zn}, \mathrm{Pb}, \mathrm{Cd}, \mathrm{Mn}, \mathrm{Cu}, \mathrm{U}$, and $\mathrm{Ba}$ in National Water Research Institute (NWRI) water certified standard, TMDA-51.2. Column 6 shows the certified values for comparison. The results obtained by the present ICP-OES method (column 4) show good agreement with the corresponding certified values (column 6). By this way, using this pattern, different type of water can be analyzed.

\section{Conclusions}

The determination of trace of elements in complex environmental materials requires essential information on the spectral interferences because the background under a prominent line cannot be directly measured and, in addition, varies with the sample composition. The correct background correction ensures the accuracy of analytical results.

The present paper presents quantitative new base data for the spectral inferences in the presence of complex matrix containing $\mathrm{Al}, \mathrm{Ca}, \mathrm{Mg}, \mathrm{Fe}$, and Ti around the wavelength $\lambda_{a}$ of the prominent lines of ten elements $(\mathrm{Zn}, \mathrm{Cd}, \mathrm{Sb}, \mathrm{Cu}, \mathrm{Mn}$, $\mathrm{Pb}, \mathrm{Sn}, \mathrm{Cr}, \mathrm{U}$, and $\mathrm{Ba}$ ) by using $40.68 \mathrm{MHz}$ ICP. The measurements were performed in the 2 nd order of the spectrum (practical spectral bandwidth $5 \mathrm{pm}$ ) for the most prominent lines of $\mathrm{Zn}, \mathrm{Cd}, \mathrm{Sb}, \mathrm{Mn}, \mathrm{Pb}, \mathrm{Sn}$, and $\mathrm{Cr}$ with wavelengths in the spectral region $160-320 \mathrm{~nm}$. The wavelengths of the most prominent lines of $\mathrm{Cu}, \mathrm{U}$, and $\mathrm{Ba}$ lie in the spectral region $320-800 \mathrm{~nm}$, and the measurements were made in the 1st order (practical spectral bandwidth $10 \mathrm{pm}$ ). In our 
previous paper, was experimentally demonstrated that the selected "best" analysis lines are the same, irrespective of ICP and operating conditions, and therefore, these data can be transferred from one ICP system to another [44].

The versatility of $Q$-concept as basic methodology was experimentally demonstrated in the determination of trace of elements in certified reference materials: IAEA/Soil 7 and NWRI water certified standard, TMDA-51.2, and a soil sample collected from relatively nonpolluted region. The obtained detection limits satisfy the quality requirements of the practice. In this paper, were shown the possibilities of the present day HR-ICP-OES equipment in the direct determination of trace elements in environmental samples (water and soil) were shown, without preconcentration of trace element of interest.

\section{References}

[1] K. S. Schwartz, "Essentiality versus toxicity of metals," in Clinical Chemistry and Chemical Toxicology of Metal, S. S. Brown, Ed., Elsevier, New York, NY, USA; North Holland, Oxford, UK, 1977.

[2] J. O. Nriagu and J. M. Pacyna, "Quantitative assessment of worldwide contamination of air, water and soils by trace metals," Nature, vol. 333, no. 6169, pp. 134-139, 1988.

[3] J. E. Forgusson, The Heavy Elements: Chemistry, Environmental Impact and Health Effects, Pergamon Press, Oxford, UK, 1990.

[4] Agency for Toxic Substances and Disease Registry, Toxicological Profile for Copper; Department of Health and Human Services, ATSDR, Atlanta, Ga, USA, 1999.

[5] R. Merget and G. Rosner, "Evaluation of the health risk of platinum group metals emitted from automotive catalytic converters," Science of the Total Environment, vol. 270, no. 1-3, pp. 165-173, 2001.

[6] M. S. Hein, "Copper deficiency anemia and nephrosis in zinctoxicity: a case report," South Dakota Journal of Medicine, vol. 56, no. 4, pp. 143-147, 2003.

[7] V. Verougstraete, D. Lison, and P. Hotz, "Cadmium, lung and prostate cancer: a systematic review of recent epidemiological data," Journal of Toxicology and Environmental Health Part B, vol. 6, no. 3, pp. 227-255, 2003.

[8] S. Kapaj, H. Peterson, K. Liber, and P. Bhattacharya, "Human health effects from chronic arsenic poisoning-a review," Journal of Environmental Science and Health Part A, vol. 41, no. 10, pp. 2399-2428, 2006.

[9] S. Bakirdere and M. Yaman, "Determination of lead, cadmium and copper in roadside soil and plants in Elazig, Turkey," Environmental Monitoring and Assessment, vol. 136, no. 1-3, pp. 401410, 2008.

[10] C. L. S. Wiseman and F. Zereini, "Airborne particulate matter, platinum group elements and human health: a review of recent evidence," Science of the Total Environment, vol. 407, no. 8, pp. 2493-2500, 2009.

[11] C. Duran, H. B. Senturk, L. Elci, M. Soylak, and M. Tufekci, "Simultaneous preconcentration of $\mathrm{Co}(\mathrm{II}), \mathrm{Ni}(\mathrm{II}), \mathrm{Cu}(\mathrm{II})$, and Cd(II) from environmental samples on Amberlite XAD-2000 column and determination by FAAS," Journal of Hazardous Materials, vol. 162, no. 1, pp. 292-299, 2009.

[12] J. Sardans, F. Montes, and J. Peñuelas, "Determination of As, Cd, $\mathrm{Cu}, \mathrm{Hg}$ and $\mathrm{Pb}$ in biological samples by modern electrothermal atomic absorption spectrometry," Spectrochimica Acta Part B, vol. 65 , no. 2, pp. 97-112, 2010.
[13] S. Bakırdere, T. Yaroğlu, N. Tirik et al., "Determination of As, $\mathrm{Cd}$, and $\mathrm{Pb}$ in tap water and bottled water samples by using optimized GFAAS system with Pd-Mg and $\mathrm{Ni}$ as matrix modifiers," Journal of Spectroscopy, vol. 2013, Article ID 824817, 7 pages, 2013.

[14] J. W. McLaren, "Applications: environmental," in Inductively Coupled Plasma Emission Spectroscopy, Part 2: Applications and Fundamentals, P. W. J. M. Boumans, Ed., Wiley, New York, NY, USA, 1987.

[15] R. E. Sturgeon, "Future of atomic spectrometry for environmental analysis: invited lecture," Journal of Analytical Atomic Spectrometry, vol. 13, no. 5, pp. 351-361, 1998.

[16] N. Velitchkova, E. N. Pentcheva, and N. Daskalova, "Determination of arsenic, mercury, selenium, thallium, tin and bismuth in environmental materials by inductively coupled plasma emission spectrometry," Spectrochimica Acta Part B, vol. 59, no. 6, pp. 871-882, 2004.

[17] K. L. Linge, “Trace element determination by ICP-AES and ICPMS: developments and applications reported during 2006 and 2007," Geostandards and Geoanalytical Research, vol. 32, no. 4, pp. 453-468, 2008.

[18] P. Petrova, S. Velichkov, N. Velitchkova, I. Havezov, and N. Daskalova, "Problems, possibilities and limitations of inductively coupled plasma atomic emission spectrometry in the determination of platinum, palladium and rhodium in samples with different matrix composition," Spectrochimica Acta Part B, vol. 65, no. 2, pp. 130-136, 2010.

[19] S. Velichkov, P. Markov, and N. Daskalova, "Determination of toxic elements in biological materials by inductively coupled plasma atomic emission spectrometry," in Proceedings of the 4th International Scientific Conference, vol. 1, pp. 353-359, Faculty of Mathematics and Natural Science, June 2011, South-West University "Neofit Rilski”, Blagoevgrad.

[20] P. P. Petrova, S. V. Velichkov, I. P. Havezov, P. Vassileva, P. Tzvetkova, and N. N. Daskalova, "Inductively coupled plasma atomic emission spectrometry-determination of platinum and palladium in environmental materials after pre concentration/separation procedure," in Proceedings of the 4th International Scientific Conference, vol. 1, pp. 335-343, Faculty of Mathematics and Natural Science, June 2011, South-West University "Neofit Rilski", Blagoevgrad.

[21] P. Petrova, N. Velitchkova, S. Velichkov, I. Havezov, and N. Daskalova, "Determination of platinum, palladium and rhodium in environmental materials by high resolution Inductively coupled plasma optical emission spectrometry (HR-ICP-OES)," in Colloquium Analytical Atomic Spectroscopy (CANAS '13), p. 75, Freiberg, Germany, March 2013, Postergruppe I, Mo 11.

[22] S. Rauch, M. Motelica-Heino, G. M. Morrison, and O. F. X. Donard, "Critical assessment of platinum group element determination in road and urban river sediments using ultrasonic nebulisation and high resolution ICP-MS," Journal of Analytical Atomic Spectrometry, vol. 15, no. 4, pp. 329-334, 2000.

[23] J. D. Whiteley and F. Murray, "Anthropogenic platinum group element $(\mathrm{Pt}, \mathrm{Pd}$ and $\mathrm{Rh}$ ) concentrations in road dusts and roadside soils from Perth, Western Australia," Science of the Total Environment, vol. 317, no. 1-3, pp. 121-135, 2003.

[24] B. Bocca, G. Forte, F. Petrucci, O. Senofonte, N. Violante, and A. Alimonti, "Development of methods for the quantification of essential and toxic elements in human biomonitoring," Annali dell'Istituto Superiore di Sanità, vol. 41, no. 2, pp. 165-170, 2005.

[25] O. T. Butler, J. M. Cook, C. M. Davidson, C. F. Harrington, and D. L. Miles, "Atomic spectrometry update. Environmental 
analysis," Journal of Analytical Atomic Spectrometry, vol. 24, no. 2, pp. 131-177, 2009.

[26] O. T. Butler, W. R. L. Cairns, J. M. Cook, and C. M. Davidson, "Atomic spectrometry update. Environmental analysis," Journal of Analytical Atomic Spectrometry, vol. 25, no. 2, pp. 103-141, 2010.

[27] ISO 11466:1995, "Soil quality-"Extraction of trace elements soluble in aqua regia',' International Organization for Standardization, 1995.

[28] M. Zischka, P. Schramel, H. Muntau et al., "A new certified reference material for the quality control of palladium, platinum and rhodium in road dust, BCR-723," Trends in Analytical Chemistry, vol. 21, no. 12, pp. 851-868, 2002.

[29] "Regulation No. 3 on the threshold concentrations of pollutant substances in soils, Ministry of Environment and Water of Bulgaria," in Bulgarian Language, 2008, http://www3.moew .government.bg/?show=top\&cid=388\&lang=bg.

[30] Milieu Ltd, WRc and Risk \& Policy Analysts Ltd (RPA), "Study on the environmental, economic and social impacts of the use of sewage sludge on land, Part III," 2010, http://ec.europa .eu/environment/waste/sludge/pdf/part_iii_report.pdf.

[31] S. C. Sheppard, M. I. Sheppard, M.-O. Gallerand, and B. Sanipelli, "Derivation of ecotoxicity thresholds for uranium," Journal of Environmental Radioactivity, vol. 79, no. 1, pp. 55-83, 2005.

[32] "Regulation No. 9 on the Quality of Water Intended for Human Consumption (State Gazette No. 30, 2001) Ministry of Environment and Water of Bulgaria," http://www3.moew .government.bg/files/file/Water/Legislation/Naredbi/vodi/ NAREDBA_9_ot_16032001_g_za_kacestvoto_na_vodata_prednaznacena_za_pitejnobitovi_celi.pdf.

[33] M. Stoeppler, Sampling and Sample Preparation, Springer, Berlin, Germany, 1997.

[34] M. Hoenig, "Preparation steps in environmental trace element analysis-facts and traps," Talanta, vol. 54, no. 6, pp. 1021-1038, 2001.

[35] P. W. J. M. Boumans, "A century of spectral interferences in atomic emission spectroscopy-can we master them with modern apparatus and approaches?" Fresenius' Zeitschrift für Analytische Chemie, vol. 324, no. 5, pp. 397-425, 1986.

[36] P. W. J. M. Boumans, "Basic concepts and characteristics of ICPAES," in Inductively Coupled Plasma Emission Spectroscopy, Part 1, Methodology, Instrumentation, and Performance, P. W. J. M. Boumans, Ed., Wiley, New York, NY, USA, 1987.

[37] P. W. J. M. Boumans, "Line selection and spectral interferences," in Inductively Coupled Plasma Emission Spectroscopy, Part 1, Methodology, Instrumentation, and Performance, P. W. J. M. Boumans, Ed., Wiley, New York, NY, USA, 1987.

[38] I. B. Brenner, A. Zander, M. Cole, and A. Wiseman, "Comparison of axially and radially viewed inductively coupled plasmas for multi-element analysis: effect of sodium and calcium," Journal of Analytical Atomic Spectrometry, vol. 12, no. 9, pp. 897906, 1997.

[39] I. B. Brenner, A. Le Marchand, C. Daraed, and L. Chauvet, "Compensation of $\mathrm{Ca}$ and $\mathrm{Na}$ interference effects in axially and radially viewed inductively coupled plasmas," Microchemical Journal, vol. 63, no. 3, pp. 344-355, 1999.

[40] E. H. van Veen and M. T. C. de Loos-Vollebregt, "On the use of line intensity ratios and power adjustments to control matrix effects in inductively coupled plasma optical emission spectrometry," Journal of analytical atomic spectrometry, vol. 14, no. 5, pp. 831-838, 1999.
[41] P. Razpotnik, B. Budič, and M. Veber, "Effects of matrix elements on the analyte emission signals in inductively coupled plasma optical emission spectrometry using a thermospray sample introduction system," Applied Spectroscopy, vol. 56, no. 8, pp. 1000-1005, 2002.

[42] S. Maestre, J. Mora, and J.-L. Todolí, "Studies about the origin of the non-spectroscopic interferences caused by sodium and calcium in inductively coupled plasma atomic emission spectrometry. Influence of the spray chamber design," Spectrochimica Acta Part B, vol. 57, no. 11, pp. 1753-1770, 2002.

[43] G. C.-Y. Chan and W.-T. Chan, "Plasma-related matrix effects in inductively coupled plasma-atomic emission spectrometry by group I and group II matrix-elements," Spectrochimica Acta Part B, vol. 58, no. 7, pp. 1301-1317, 2003.

[44] N. Velitchkova, S. Velichkov, and N. Daskalova, "Inductively coupled plasma atomic emission spectrometry-optimization of the operating conditions in the determination of trace of elements in line-rich emission matrices," Spectrochimica Acta Part B, vol. 62, no. 4, pp. 386-402, 2007.

[45] J. W. McLaren and J. M. Mermet, "Influence of the dispersive system in inductively coupled plasma atomic emission spectrometry," Spectrochimica Acta Part B, vol. 39, no. 9-11, pp. 1307$1322,1984$.

[46] J. W. Olesik, "Spectrometers," in Inductively Coupled Plasma Emission Spectroscopy, Part 1, Methodology, Instrumentation, and Performance, P. W. J. M. Boumans, Ed., Wiley, New York, NY, USA, 1987.

[47] P. W. J. M. Boumans and J. J. A. M. Vrakking, "Line selection in atomic emission spectrometry using physically resolved spectra," Spectrochimica Acta Part B, vol. 43, no. 1, pp. 69-74, 1988.

[48] P. W. J. M. Boumans, J. A. Tielrooy, and F. J. M. J. Maessen, "Mutual spectral interferences of rare earth elements in inductively coupled plasma atomic emission spectrometry. I. Rational line selection and correction procedure," Spectrochimica Acta Part B, vol. 43, no. 2, pp. 173-199, 1988.

[49] P. W. J. M. Boumans and J. J. A. M. Vrakking, "Detection limit including selectivity as a criterion for line selection in trace analysis using inductively coupled plasma-atomic emission spectrometry (ICP-AES)-a tutorial treatment of a fundamental problem of AES," Spectrochimica Acta Part B, vol. 42, no. 6, pp. 819-840, 1987.

[50] P. W. J. M. Boumans, "Atomic emission detection limits; more than incidental analytical figures of merit! - a tutorial discussion of the differences and links between two complementary approaches," Spectrochimica Acta Part B, vol. 46, no. 6-7, pp. 917939, 1991.

[51] P. W. J. M. Boumans, "Detection limits and spectral interferences in atomic emission spectrometry," Analytical Chemistry, vol. 66 , no. $8,1994$.

[52] J. M. Mermet, "Spectroscopic diagnostics: basic concepts," in Inductively Coupled Plasma Emission Spectroscopy, Part 1, Methodology, Instrumentation and Performance, P. W. J. M. Boumans, Ed., Wiley, New York, NY, USA, 1987.

[53] P. W. J. M. Boumans and J. J. A. M. Vrakking, "The widths and shapes of about 350 prominent lines of 65 elements emitted by an inductively coupled plasma," Spectrochimica Acta Part B, vol. 41, no. 12, pp. 1235-1275, 1986.

[54] P. W. J. M. Boumans and J. J. A. M. Vrakking, "Inductively coupled plasmas: line widths and shapes, detection limits and spectral interferences. An integrated picture: plenary lecture," 
Journal of Analytical Atomic Spectrometry, vol. 2, no. 6, pp. 513$525,1987$.

[55] ISO 10381-2:2002, "Soil quality—sampling_part 2: guidance on sampling techniques," International Organization for Standardization, 2002.

[56] P. W. J. M. Boumans, Line Coincidence Tables for Inductively Coupled Plasma Atomic Emission Spectrometry, Pergamon, Oxford, UK, 1980.

[57] Iv. Boevski, N. Daskalova, and I. Havezov, "Determination of barium, chromium, cadmium, manganese, lead and zinc in atmospheric particulate matter by inductively coupled plasma atomic emission spectrometry (ICP-AES)," Spectrochimica Acta Part B, vol. 55, no. 11, pp. 1643-1657, 2000.

[58] K. Doerffel, Statistik in der Analytischen Chemie, VEB Deutscher Verlag für Grundstoffindustrie, Leipzig, Germany, 1984.

[59] D. Kar, P. Sur, S. K. Mandal, T. Saha, and R. K. Kole, "Assessment of heavy metal pollution in surface water," International Journal of Environmental Science and Technology, vol. 5, no. 1, pp. 119124, 2008.

[60] Y. Sanayei, N. Ismail, and S. M. Talebi, "Determination of heavy metals in Zayandeh Rood River, Isfahan-Iran," World Applied Sciences Journal, vol. 6, no. 9, pp. 1209-1214, 2009.

[61] H. Rubio-Arias, C. Quintana, J. Jimenez-Castro, R. Quintana, and M. Gutierrez, "Contamination of the Conchos river in Mexico: does it pose a health risk to local residents?" International Journal of Environmental Research and Public Health, vol. 7, no. 5, pp. 2071-2084, 2010.

[62] M. M. El Bouraie, A. A. El Barbary, M. M. Yehia, and E. A. Motawea, "Heavy metal concentrations in surface river water and bed sediments at Nile Delta in Egypt," Suoseura-Finnish Peatland Society, vol. 61, no. 1, pp. 1-12, 2010.

[63] EN ISO 11855, "Water quality-determination of selected elements by inductively coupled plasma optical emission spectroscopy (ICP-OES)," ISO: 11885:2007, 2009.

[64] G. R. Harrison, MIT Wavelength Tables, M.I.T. Press, Cambridge, Mass, USA, 1969.

[65] A. N. Zaidel, V. K. Prokofèv, S. M. Raiskii, V. A. Slavnyi, and E. Ya. Shreider, Tables of Spectral Lines, IFI/Plenum, New York, NY, USA, 1970. 

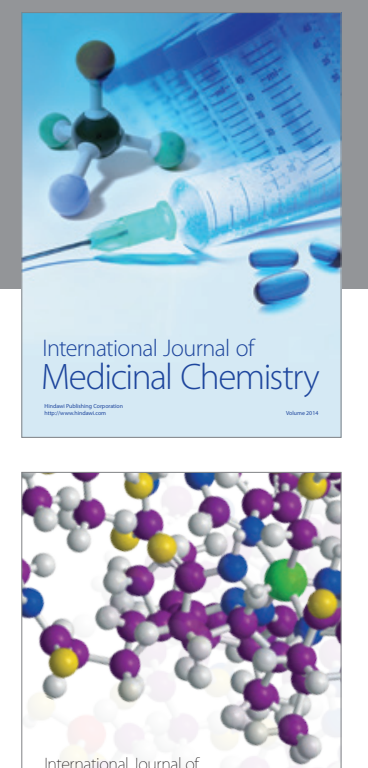

\section{Carbohydrate} Chemistry

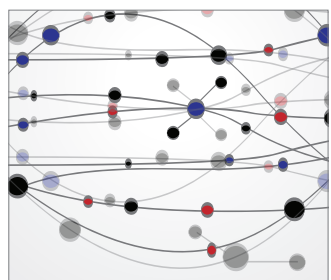

The Scientific World Journal
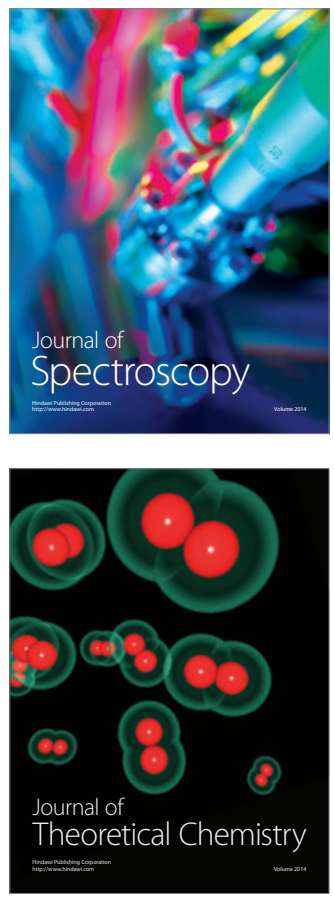
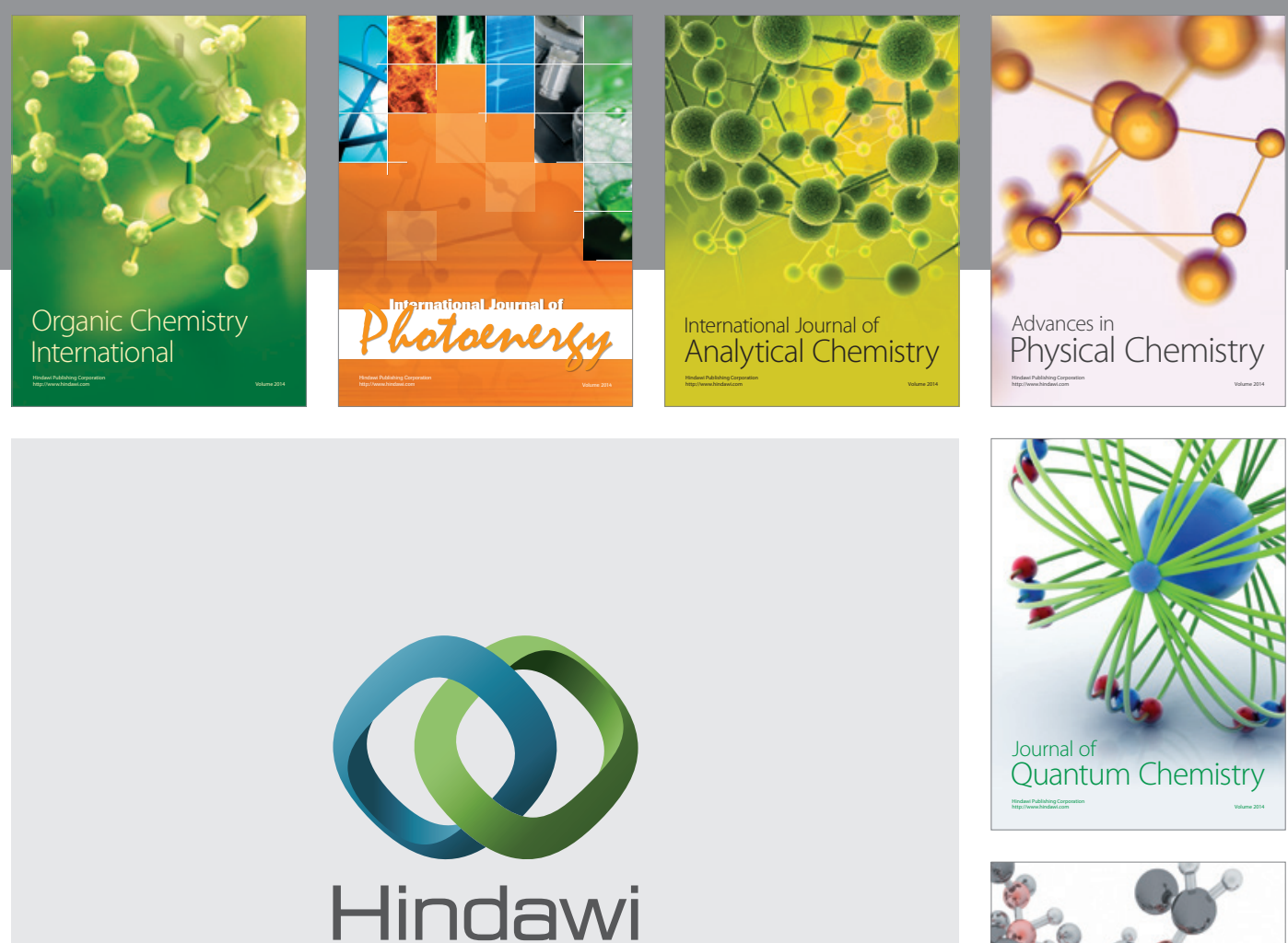

Submit your manuscripts at

http://www.hindawi.com

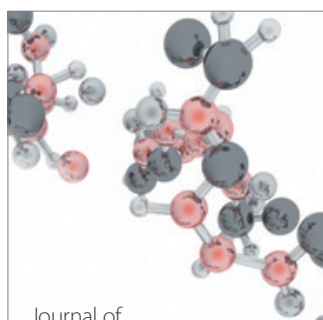

Analytical Methods

in Chemistry

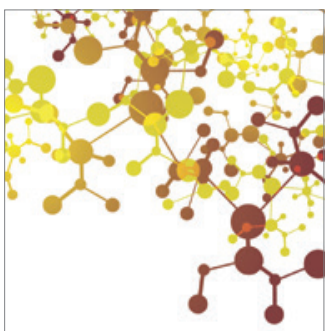

Journal of

Applied Chemistry

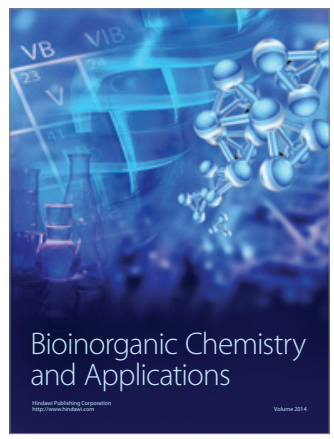

Inorganic Chemistry
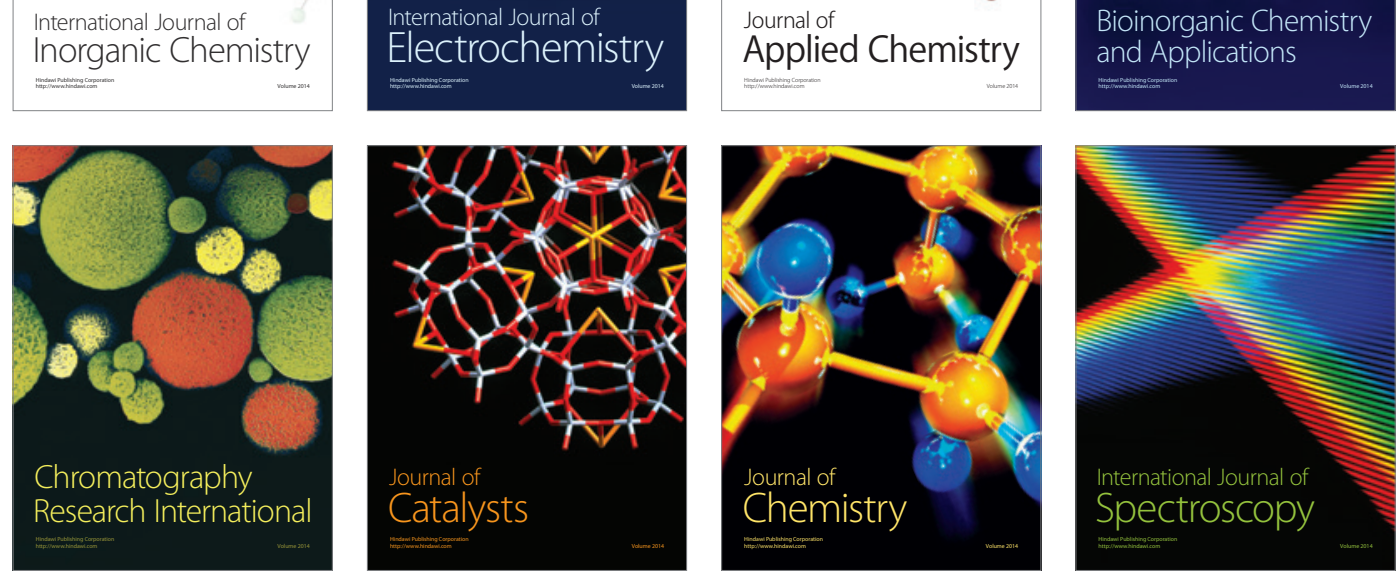